\title{
Novel diagnostic approaches and biological therapeutics for intrinsic asthma
}

REVIEW

This article was published in the following Dove Press journal:

International Journal of General Medicine

8 July 2014

Number of times this article has been viewed

\author{
María del Carmen Vennera ${ }^{1-3}$ \\ César Picadol-3 \\ 'Department of Pneumology and \\ Respiratory Allergy, Hospital Clínic, \\ Universitat de Barcelona, Barcelona, \\ Spain; ${ }^{2}$ Institut d'Investigacions \\ Biomèdiques August $\mathrm{Pi}$ i Sunyer \\ (IDIBAPS), Barcelona, Spain; ${ }^{3}$ Centro \\ de Investigaciones Biomédicas en \\ Red de Enfermedades Respiratorias \\ (CIBERES), Spain
}

\begin{abstract}
Intrinsic asthma has been considered as a specific disease entity for a long time, although many controversies have emerged in relation to this concept. Of note, not finding specific allergen sensitization in an asthmatic patient neither excludes an allergic component nor the essential role that immunoglobulin E may play in asthma. The diagnostic approach should be similar in any patient suspected to have asthma. The atopic status is one among many other questions. Omalizumab, the only monoclonal anti-immunoglobulin E antibody commercialized for asthma, should be tried in patients with uncontrolled severe asthma independent of their atopic status.
\end{abstract}

Keywords: nonatopic asthma, immunoglobulin E, omalizumab

\section{Introduction}

In 1990, Claude Molina published a paper in the Bulletin de l'Academie Nationale de Medecine entitled "Predicting announcement of the death of intrinsic asthma", arguing that intrinsic asthma should be removed from the medical vocabulary. ${ }^{1}$ Molina based his assertions on past history, clinical symptoms, molecular biology, and genetics, and stated that asthma appeared to be a local variety of immunoglobulin (Ig)E hyperresponsiveness to environmental factors. In 1918, Frances Rackemann had published a paper entitled "A clinical study of 150 cases of bronchial asthma", ${ }^{2}$ suggesting that not all asthma could be defined as allergic, so categorized asthma cases as either extrinsic or intrinsic. Extrinsic asthma is when an asthmatic has a hypersensitivity to a protein in foreign objects, or things that are outside the human body. Their bodies develop proteins (later identified as IgE antibodies) to these substances, and repeated exposure to these foreign proteins will cause the allergic asthma response. Intrinsic asthma would cover all those cases of asthma not attributable to allergies, such as asthma caused by sinus infections, chronic sinusitis, nasal polyps, teeth infections, gum infections, throat infections (croup), acute bronchitis, colds, kidney failure (kidney asthma), heart failure (cardiac asthma), gastrointestinal irritation, etc. It usually affects adults more so than children, and is more likely to be chronic than extrinsic asthma. Rackemann explained that although there were clinical differences between intrinsic and extrinsic asthma, their clinical symptoms and associated respiratory function were very similar. ${ }^{2}$ Ever since this early description, there has been debate about the role of atopy in intrinsic asthma.

At this point, it would be helpful to define the concepts of atopy and allergy. Atopy is a genetic predisposition to develop a hypersensitivity reaction and produce elevated
Vennera

Servei de Pneumologia i Allèrgia,

Hospital Clinic, Villarroel I70,

08036 Barcelona, Spain

Tel +34932275540

$\mathrm{Fax}+34932279813$

Email cvennera@clinic.ub.es 
levels of IgE upon exposure to an antigen (mostly inhaled or ingested) that other people do not react to. Normally, atopy and allergy are terms that are used synonymously, but allergy should be used when atopy is associated with symptoms of disease, eg, rhinitis, asthma, atopic dermatitis, urticaria, angioedema, anaphylaxis, abdominal pains, or diarrhea.

Nowadays, although many studies have confirmed that intrinsic and extrinsic asthma have similar physiopathology, the dichotomy still exists, with different therapeutic options for each. The present review analyzes the relevance of differences between intrinsic and extrinsic asthma in light of new trends, reviews the diagnostic approach to so-called intrinsic asthma, and evaluates the role of new biological therapies according to the atopy status of asthma.

\section{Immunopathology}

The pathology of intrinsic asthma and that of extrinsic asthma are quite similar. Activation of mast cells, basophils, and Thelper type 2 (Th2) cells results in production of cytokines, including interleukin (IL)-4 and IL-13, which coordinate and amplify the inflammatory cascade. Subsequently, B-cells initiate the transcription and production of allergen-specific IgE. The crystallizable fraction $(\mathrm{Fc})$ of free $\mathrm{IgE}$ molecules binds to the surface of mast cells, basophils, macrophages, and dendritic cells via high-affinity (FceRI) and low-affinity (FceRII) receptors. Allergens then bind to the variable region of the bound IgE molecule, inducing cell activation and generation of proinflammatory mediators, including Th2-type cytokines, chemokines, prostaglandin D2, leukotriene C4, and tumor necrosis factor- $\alpha$. This process augments the recruitment of additional eosinophils, basophils, and Th2 cells, ultimately resulting in mucosal inflammation, air hyperresponsiveness, airflow limitation, and symptoms of asthma. ${ }^{3}$

Humbert et $\mathrm{al}^{4,5}$ have contributed to our understanding of the pathology of asthma with numerous studies. In one of these studies, ${ }^{4}$ allergic and nonallergic patients underwent bronchial biopsy studies. Variants of the disease were characterized by: infiltration of eosinophils and Th2 cells secreting IL-4 or IL-5, or both; the presence of chemokines and FceRI ${ }^{+}$cells; and cells that express mRNA for the $\varepsilon$ germ-line transcript (I $\varepsilon$ ) and the $\varepsilon$ heavy chain of $\operatorname{IgE}(\mathrm{C} \varepsilon)$. The only difference found was a strong macrophage signal in biopsies from patients with intrinsic asthma when compared with those with extrinsic asthma. Humbert et al suggested that this could represent macrophage dysfunction or simply be a reflection of age and duration of disease (intrinsic asthmatics were significantly older) rather than a basic difference in the pathological mechanism between these two forms of asthma. ${ }^{4,5}$ Similarly, FceRI are expressed in allergic and nonallergic asthma. ${ }^{6}$

IL-4 is essential for synthesis of IgE, and there is much evidence that IL-5 plays a major role in recruitment of eosinophils in the inflammation component of asthma. Humbert et $\mathrm{al}^{7}$ compared the expression of IL-4 and IL-5 mRNA and their protein products in bronchial biopsies from symptomatic atopic and nonatopic asthmatic subjects and that in atopic and nonatopic controls. Compared with controls, biopsies from both groups of asthmatic subjects showed increased numbers of IL-4 and IL-5 mRNA copies relative to beta-actin mRNA as detected by reverse transcription polymerase chain reaction. Similarly, in situ hybridization and immunohistochemistry demonstrated increased numbers of cells expressing IL-4 and IL-5 mRNA and protein in asthmatic subjects, irrespective of their atopy status. They concluded that individuals with asthma, whether atopic or nonatopic, showed infiltration of the bronchial mucosa with cells expressing Th2-type cytokines, providing further evidence for similarities in the immunopathology of these clinically distinct forms of asthma.

The relationship between elevated levels of total $\operatorname{IgE}$ and asthma, independent of atopy status, has been well documented. ${ }^{8-10}$ Humbert $^{11}$ confirmed that nonatopic asthmatics have elevated total serum $\operatorname{IgE}$ concentrations when compared with nonatopic controls, despite the fact that, as a group, nonatopic asthmatics tend to be older than allergic asthmatics and serum IgE concentrations tend to decline with age.

As well as elevated total serum IgE, evidence for local synthesis of $\operatorname{IgE}$ has been demonstrated in the airways of patients with intrinsic asthma, despite negative skin prick tests and negative testing for allergen-specific IgE in serum. ${ }^{12,13}$ This local IgE and FceRI expression suggests that patients labeled as having intrinsic asthma might be allergic to an unidentified exogenous antigen, an infective agent, or an endogenous allergen due to local allergic reactions in the airways.

The Staphylococcus aureus enterotoxin reaction deserves special mention. $S$. aureus frequently colonizes the human nose, mostly in patients with nasal polyp disease. $S$. aureus has the potential to release enterotoxins that may act as superantigens, polyclonally activating T-cells and B-cells directly within the human mucosa. IgE antibodies against $S$. aureus enterotoxins (SAE-IgE) may therefore serve as a marker of this polyclonal activation, either locally within the mucosa or systemically in the serum. SAE-IgE can be measured in the serum of patients who have chronic rhinosinusitis 
with nasal polyps and comorbid asthma, as well as in patients with asthma alone.

The presence of intramucosal SAE-IgE in polyps is common when nasosinusal pathology is associated with asthma, mostly severe asthma. About $60 \%-80 \%$ of patients with severe asthma are SAE-IgE-positive, and about one third are nonatopic, suggesting that superantigens may be a cause of the so-called intrinsic form of asthma. ${ }^{14}$

All in all, there are no significant physiopathological differences between intrinsic and extrinsic asthma.

\section{Phenotypes}

Asthma has been generally recognized as a very complex and heterogeneous disease that is variable over time. The concept of "phenotype" was introduced to provide a more integrated classification. It is defined as the grouping of characteristics of an organism that result from the interaction of genes with the environment. ${ }^{15}$ Phenotypic heterogeneity reflecting the diverse genetic and complex environmental factors implicated in the pathogenesis of asthma is an evolving concept. First, descriptions focused on the two main phenotypes of asthma, ie, extrinsic and intrinsic. Discrepancies concerning this division justified further studies to differentiate these phenotypes, taking into account epidemiological and clinical data, the natural history of the disease, and the pathophysiology of the airways. In the end, the objective of phenotype classification would be to design specific therapeutic strategies for each phenotype.

Classification of phenotypes is based empirically on the principle that similarity measured across a number of different characteristics may predict relationships of biological significance with greater probability. Cluster analysis refers to a group of multivariate mathematical algorithms that, broadly, quantify similarity between individuals and group individuals into clusters such that similarity between members of the same clusters is strong. ${ }^{16,17}$

Three recent studies have described clusters fundamentally based on the age of onset of asthma, sex, atopic status, asthma symptoms, and lung function plus other items that were particular to each study. Interestingly, some phenotypes identified by all three analyses overlapped. Of note, they identified a phenotype composed of subjects with earlyonset allergic asthma, and another phenotype composed mainly of females with late-onset nonallergic asthma and a higher percentage of neutrophils in sputum. ${ }^{17-20}$ Haldar et al ${ }^{17}$ did not identify atopic status as a significant discriminator influencing cluster; however, the prevalence of atopy did differ significantly between clusters, suggesting that its inclusion to describe phenotypes is appropriate.
In a recent exhaustive review of adult-onset asthma, de Nijs et $\mathrm{al}^{21}$ considered that the differentiation between childhood-onset asthma and adult-onset asthma is not new, and with the importance of phenotyping of asthma being increasingly recognized, the adult-onset asthma described by Rackemann in $1947^{22}$ seems to have been "rediscovered". Within adult-onset asthma, the authors described:

- Adult-onset obese female-preponderant asthma, with high symptomatology, less atopy, no eosinophilic airway inflammation, often treated with systemic corticosteroids

- Adult-onset nonatopic asthma, mainly affecting males, with fixed airflow limitation, eosinophilia in sputum, frequent exacerbations, an association with chronic rhinosinusitis, nasal polyps, and aspirin sensitivity

- Adult-onset mild asthma, mainly affecting females, around $50 \%$ of whom are atopic, not fixed airflow obstruction, less smoking history, lower body mass index

- Smoking-related asthma, mostly males, about $66 \%$ nonatopic, not fixed airflow obstruction.

Compared with childhood-onset asthma, adult-onset asthma has a worse prognosis, a poorer response to standard treatment, and often requires systemic corticosteroids. Nonatopic or intrinsic asthma is associated with more severe disease, but it can be present in more than one of the different adult-onset phenotypes.

Neutrophilia has been associated with severe asthma and was supported as a specific phenotype (neutrophilic asthma) with discrepancies. ${ }^{23-25}$ Neutrophilia can coexist with eosinophilia, and this identifies people with the most severe asthma and underscores the complexity of the immune biology of severe asthma, in which multiple innate and adaptive immune pathways and cells may have a role.

Taken together, a number of studies have confirmed that asthma is a very heterogeneous disease, but also demonstrate that phenotype classification is plagued by confounding issues.

\section{Diagnostic approach}

The diagnostic approach to asthma is very well described nowadays in international and national guidelines. ${ }^{26,27}$ As always in medicine, the clinical history (anamnesis) is the first and certainly the principal initial approach for diagnosing asthma. Diagnostic tests must confirm the diagnosis, considering all possible confounders that in some cases may be very difficult. Table 1 is a summary of the most important steps in confirming a diagnosis of asthma. 
The steps for diagnosing asthma must be the same in every case. This basic approach and other specialized tests contribute to establishing a phenotype in an individual patient. In particular, the atopy status approach is as important as any other part of the diagnosis. In many cases, confirmation of atopy status is not possible.

\section{Biological treatment}

In general, most patients with asthma can be well controlled by daily therapy combining inhaled corticosteroids with a long-acting $\beta 2$-agonist, as recommended by international and national guidelines. ${ }^{26,27}$ Addition of other controllers, including oral corticosteroids, may be necessary in patients with more severe asthma. However, around $10 \%$ of patients respond poorly to conventional treatment, being exposed to the severe adverse effects of treatment and having a poor quality of life. These patients generate most of the health care costs associated with asthma. This group highlights a clear need for improved treatment strategies, such as biological therapies. Our current understanding of the immune pathology of asthma has identified multiple mediators as potential therapeutic targets, and these are currently under development. To date, most of these monoclonal antibodies have focused on the Th2 asthma phenotype, but little is known about their efficacy in so-called nonatopic asthma. To our knowledge, only two have been investigated in "intrinsic asthma".

\section{Omalizumab}

Up until now, the first and as yet only biological agent licensed for the treatment of asthma is omalizumab (Xolair ${ }^{\circledR}$; Novartis Europharm Limited, Horsham, West

Table I Diagnostic approach to asthma

\begin{tabular}{|c|c|}
\hline Clinical history & Diagnostic tests \\
\hline $\begin{array}{l}\text { General data: age, sex, height, and weight } \\
\text { (body mass index), smoking }\end{array}$ & $\begin{array}{l}\text { Spirometry with a } \\
\text { bronchodilator test }\end{array}$ \\
\hline Family history: asthma and atopic status & $\begin{array}{l}\text { Nonspecific bronchial } \\
\text { provocation test }\end{array}$ \\
\hline $\begin{array}{l}\text { Personal history: atopic dermatitis, allergic } \\
\text { rhinitis, and conjunctivitis, other allergies }\end{array}$ & $\begin{array}{l}\text { Common aeroallergen } \\
\text { skin tests }\end{array}$ \\
\hline $\begin{array}{l}\text { History of asthma: age of onset, severity } \\
\text { at baseline, treatments performed and } \\
\text { response, asthma admissions, requirement } \\
\text { for mechanical ventilation for asthma }\end{array}$ & Total serum lgE levels \\
\hline $\begin{array}{l}\text { Background: chronic rhinosinusitis with } \\
\text { or without polyposis; sense of smell }\end{array}$ & Specific serum IgE levels \\
\hline $\begin{array}{l}\text { Background intolerance to nonsteroidal } \\
\text { anti-inflammatory drugs }\end{array}$ & $\begin{array}{l}\text { Peripheral blood } \\
\text { eosinophil count }\end{array}$ \\
\hline Background: gastroesophageal reflux & Sputum eosinophil count \\
\hline
\end{tabular}

Abbreviation: IgE, immunoglobulin E.
Sussex, UK), specifically for severe extrinsic asthma. The essential role of $\operatorname{IgE}^{28}$ in the pathogenesis of asthma has been broadly recognized, ${ }^{3}$ as mentioned above, justifying the view of $\operatorname{IgE}$ as a target for new monoclonal antibodies. As a consequence, the anti-IgE concept was proposed by Chang et al in early $1987 .{ }^{29}$

Omalizumab is a humanized monoclonal antibody that binds to the $\mathrm{Fc}$ of free $\mathrm{IgE}$ molecules, reducing free circulating $\operatorname{IgE}$ and blocking its binding to the receptors present on mast cells, basophils, and dendritic cells, which prevents inflammatory cells from releasing mediators when in contact with allergens. More mechanisms of action have also been described over time. Omalizumab decreases the density of FceRI and FceRII expression on basophils, mast cells, and dendritic cells, and decreases airway inflammation. ${ }^{3}$ A reduction in expression of FceRI on dendritic cells and its binding to $\operatorname{IgE}$ may decrease the allergen presentation process. Further, recent studies have shown that omalizumab might have some benefit in airway remodeling by reducing the thickness of the reticular basement membrane in patients with asthma. ${ }^{30,31}$

Omalizumab has demonstrated its efficacy in severe IgEmediated allergic asthma, both in clinical studies and in the post-marketing experience. ${ }^{32-37}$ First approved in Australia in 2002, omalizumab was authorized in Spain in 2006. Table 2 describes the approved indications for patients with asthma who have not responded to conventional treatments. Doses are calculated according to body weight and total IgE levels. Doses may range between $75 \mathrm{mg}$ and $600 \mathrm{mg}$ every 4 weeks or $225 \mathrm{mg}$ and $600 \mathrm{mg}$ every 2 weeks. ${ }^{38}$

Asthma is a heterogeneous disease in which $\operatorname{IgE}$ may play different roles, and non-atopy status is associated with more severe disease. Therefore, investigating whether omalizumab has a role to play in nonallergic asthmatics became necessary. Starting with isolated case reports, clinical data has emerged for a substantial number of patients with uncontrolled intrinsic asthma from clinical trials and "real life" studies, showing a reduction in exacerbation rates and

Table 2 Approved indications for omalizumab

Xolair is indicated as add-on therapy in adults, adolescents, and children ( $>6$ years) with severe persistent allergic asthma not controlled with common medication and

- Positive skin test reactions or specific lgE to a perennial aeroallergen

- Reduced lung function (FEV,$<80 \%$ predicted)

- $\lg \mathrm{E} 30-1,500 \mathrm{IU} / \mathrm{mL}$

- With nocturnal awakenings and/or frequent daytime symptoms

- With multiple severe exacerbations

Abbreviations: IgE, immunoglobulin E; FEV , forced expiratory volume in I second. 
an improvement in symptom scores during treatment with omalizumab. ${ }^{39-43}$ In our series, ${ }^{42}$ omalizumab demonstrated a beneficial effect in a group of 29 patients with nonatopic asthma. Over the course of the study, the Global Evolution of Treatment Effectiveness scale and Asthma Control Test score increased significantly. Further, we observed an increase in pulmonary function values and a decrease in severe asthma exacerbations, but these were not significantly different from that achieved in atopic asthmatics. All in all, the global results were very similar to those obtained in atopic patients.

Barnes, ${ }^{44}$ in his review on intrinsic asthma, considered that the demonstration that intrinsic asthma is associated with local IgE production, as in the case of superantigens, suggests that treatment with anti-IgE may be appropriate in nonatopic asthma. Another two possible explanations are considered by Bhat and Calhoun, ${ }^{3}$ who theorized that the range of potential allergenic agents is considerably larger than that addressed by the currently available diagnostic reagents, so "false-negative" allergy test results are a real possibility. Alternatively, it is possible that $\operatorname{IgE}$ elevation may occur as an unspecific reaction, secondary to asthmatic Th2 cell-like inflammation with IL-4 elaboration, and that $\operatorname{IgE}$ triggers airway hyperresponsiveness independent of a specific allergen sensitization.

Finally, in a recent publication, Lommatzsch et $\mathrm{al}^{45}$ argue that there are currently two hypotheses that might explain the clinical effects of omalizumab in patients with intrinsic asthma. The first one assumes that patients with intrinsic asthma have a local allergy with elevated concentrations of allergen-specific IgE antibodies in the airways. In this case, treatment with anti-IgE could reduce local allergic airway inflammation, leading to a reduction in disease severity and exacerbation rates. The other hypothesis assumes that plasmacytoid dendritic cells in patients with intrinsic asthma are characterized by an immunological imbalance, and enhanced cross-linking of FceRI on plasmacytoid dendritic cells suppresses the antiviral activity of these cells. In this case, viral infections could trigger intrinsic asthma. Anti-IgE treatment could reduce serum IgE concentrations and the density of $\operatorname{IgE}$ receptors on plasmacytoid dendritic cells, thereby restoring the antiviral activity of plasmacytoid dendritic cells and decreasing the disease severity and exacerbation rates. More specifically, in the first randomized controlled study comparing omalizumab and placebo in intrinsic asthma, Garcia et $\mathrm{al}^{43}$ showed that FceRI expression on blood plasmacytoid dendritic cells decreased markedly (by 56\%) in omalizumab-treated patients as compared with a nonsignificant change of $4 \%$ in those given placebo.
All in all, the recent molecular and clinical evidence suggests that anti-IgE treatment may be effective in patients with intrinsic asthma. As Lommatzsch et al point out, this is more than just anecdotal evidence, so well controlled clinical trials of anti-IgE are urgently needed in patients with intrinsic asthma.

\section{Mepolizumab}

Mepolizumab is a humanized monoclonal antibody against IL-5 and selectively and effectively inhibits eosinophilic inflammation in the airways. In 2012, a large study demonstrated the efficacy of mepolizumab in reducing the exacerbation rate in patients with severe eosinophilic asthma. ${ }^{46}$ Further, another recent study also demonstrated that mepolizumab is effective in the treatment of severe nasal polyposis. ${ }^{47}$

Eosinophils are involved in diverse inflammatory responses irrespective of atopy status and IL-5 is involved primarily in growth, survival, and activation of eosinophils, as well as in mediating inflammation. Therefore, Ortega et $\mathrm{al}^{48}$ conducted a post hoc analysis of the DREAM trial (ClinicalTrials.gov identifier NCT01000506), ${ }^{46}$ with the objective of examining and discussing the effect of treatment with mepolizumab on the frequency of exacerbations in atopic and nonatopic subgroups. These authors concluded that treatment with mepolizumab resulted in a consistent reduction in eosinophils and a decreased exacerbation frequency in both atopic and nonatopic patients (42\% and 51\%, respectively). Mepolizumab may be promising for patients with severe eosinophilic asthma irrespective of atopy status.

\section{Take home messages}

In light of new trends, some reflections are possible:

- asthma is a very heterogeneous disease

- there are more similarities than differences between extrinsic and intrinsic asthma

- advances in knowledge have led to identification of different phenotypes based on various clinical and biopathological characteristics

- evolution of "cluster" analysis contributes to better identification of phenotypes

- atopy status is one of the different characteristics that may be present in several phenotypes

- not finding a specific allergen does not mean absence of atopy

- intrinsic status is associated with more severe asthma

- although identification of atopic status may not be a criterion for classification of asthma, it may help to guide treatment and prevention of exposure to the proposed cause 
- the diagnostic approach must be equal to that for any suspected asthma patient

- there is emerging evidence that omalizumab may be beneficial for patients in whom atopy status cannot be identified and should be considered in uncontrolled severe asthma.

As Molina said a long time ago, ${ }^{1}$ intrinsic asthma has no place in the medical vocabulary as a unique entity; moreover, using this concept may act as a confounder. However, studying atopy status is essential, as for any other different characteristic, to identify asthma patients.

\section{Acknowledgments}

The authors thank Dr Mariona Pascal for critical revision and helpful discussion of the manuscript, and Dr Joan Bartra for daily encouragement.

\section{Disclosure}

$\mathrm{MdCV}$ and $\mathrm{CP}$ have received payments from Novartis for lectures and consultancy work, and support for attendance of scientific meetings.

\section{References}

1. Molina C. Chronique d'une mort annoncée: la fin de l'asthme intrinsèque. [Predicting death announcement of "intrinsic" asthma.] Bull Acad Natl Méd. 1990;174(6):799-805. French.

2. Rackemann FM. A clinical study of one hundred and fifty cases of bronchial asthma. Arch Intern Med. 1918;22(4):517-522.

3. Bhat KD, Calhoun WJ. Omalizumab in asthma: is the therapeutic window too small? Chest. 2011;139(1):8-10.

4. Humbert M, Menz G, Ying S, et al. The immunopathology of extrinsic (atopic) and intrinsic (non-atopic) asthma: more similarities than differences. Immunol Today. 1999;20(11):528-533.

5. Humbert M. L'asthme "intrinsèque" existe-til? [Is there such a thing as "intrinsic" asthma?] Rev Mal Respir. 2000;17(1 Pt 2):245-254. French.

6. Humbert M, Grant JA, Tabora-Barata L, et al. High affinity IgE receptor (FCERI)-bearing cells in bronchial biopsies from atopic and non-atopic asthma. Am J Respir Crit Care Med. 1996;153(6 Pt 1):1931-1937.

7. Humbert M, Durham SR, Ying S, et al. IL-4 and IL-5 mRNA and protein in bronchial biopsies from patients with atopic and nonatopic asthma: evidence against "intrinsic" asthma being a distinct immunopathologic entity. Am J Respir Crit Care Med. 1996;154(5):1497-1504.

8. Burrows B, Martinez FD, Halonen M, Barbee RA, Cline MG. Association of asthma with serum IgE levels and skin-test reactivity to allergens. N Engl J Med. 1989;320(5):271-277.

9. Sunyer J, Antó JM, Castellsagué J, Soriano JB, Roca J; The Spanish Group of the European Study of Asthma. Total serum IgE is associated with asthma independently of specific IgE levels. Eur Respir J. 1996;9(9):1880-1884.

10. Beeh KM, Ksoll M, Buhl R. Elevation of total serum immunoglobulin E is associated with asthma in nonallergic individuals. Eur Respir $J$. 2000;16(4):609-614.

11. Humbert M. [Bronchial immunoglobulin $\mathrm{E}$ production in intrinsic asthma]. Rev Fr Allergol. 2003;43:229-231. French.

12. Ying S, Humbert M, Meng Q, et al. Local expression of epsilon germline gene transcripts and RNA for the epsilon heavy chain of $\operatorname{IgE}$ in the bronchial mucosa in atopic and nonatopic asthma. JAllergy Clin Immunol. 2001;107(4):686-692.
13. Mouthuy J, Detry B, Sohy C, Pirson F, Pilette C. Presence in sputum of functional dust mite-specific IgE antibodies in intrinsic asthma. Am J Respir Crit Care Med. 2011;184(2):206-214.

14. Bachert C, Zhang N. Chronic rhinosinusitis and asthma: novel understanding of the role of IgE 'above atopy'. J Intern Med. 2012;272(2): 133-143.

15. An encyclopedia Britannica company; 2011. Available from: http:// global.britannica.com/EBchecked/topic/455632/phenotype. Accessed June 23, 2014.

16. Wenzel SE. Asthma: defining of the persistent adult phenotypes. Lancet. 2006;368(9537):804-813.

17. Haldar P, Pavord ID, Shaw DE, et al. Cluster analysis and clinical asthma phenotypes. Am J Respir Crit Care Med. 2008;178(3):218-224.

18. Corren J. Asthma phenotypes and endotypes: an evolving paradigm for classification. Discov Med. 2013;15(83):243-249.

19. Moore WC, Meyers DA, Wenzel SE, et al. Identification of asthma phenotypes using cluster analysis in the Severe Asthma Research Program. Am J Respir Crit Care Med. 2010;181(4):315-323.

20. Siroux V, Basagaña X, Boudier A, et al. Identifying adult asthma phenotypes using a clustering approach. Eur Respir J. 2011;38(2): 310-317.

21. de Nijs SB, Venekamp LN, Bel EH. Adult-onset asthma: is it really different? Eur Respir Rev. 2013;22(127):44-52.

22. Rackemann FM. A working classification of asthma. Am J Med. 1947;3(5):601-606.

23. Wenzel SE. Asthma phenotypes: the evolution from clinical to molecular approaches. Nat Med. 2012;18(5):716-725.

24. Jatakanon A, Uasuf C, Maziak W, Lim S, Chung KF, Barnes PJ. Neutrophilic inflammation in severe persistent asthma. Am J Respir Crit Care Med. 1999;160(5 Pt 1):1532-1539.

25. Kim HY, DeKruyff RH, Umetsu DT. The many paths to asthma: phenotype shaped by innate and adaptive immunity. Nat Immunol. 2010;11(7):577-584.

26. Global Initiative for Asthma. Global strategy for asthma management and prevention. Available from: http://www.ginasthma.org. Accessed June 6, 2014.

27. GEMA (Spanish Guideline on the Management of Asthma). Arch Bronconeumol. 2009;45(Suppl 7):2-35.

28. Ishizaka K, Ishizaka T. Identification of gamma-E-antibodies as a carrier of reaginic activity. J Immunol. 1967;99(6):1187-1198.

29. Chang TW, Wu PC, Hsu CL, Hung AF. Anti-IgE antibodies for the treatment of IgE-mediated allergic diseases. Adv Immunol. 2007;93: 63-119.

30. Riccio AM, Dal Negro RW, Micheletto C, et al. Omalizumab modulates bronchial reticular basement membrane thickness and eosinophil infiltration in severe persistent allergic asthma patients. Int J Immunopathol Pharmacol. 2012;25(22):475-484.

31. Hoshino M, Ohtawa J. Effects of adding omalizumab, an antiimmunoglobulin $\mathrm{E}$ antibody, on airway wall thickening in asthma. Respiration. 2012;83(6):520-528.

32. Humbert M, Beasley R, Ayres J, et al. Benefits of omalizumab as add-on therapy in patients with severe persistent asthma who are inadequately controlled despite best available therapy (GINA 2002 step 4 treatment): INNOVATE. Allergy. 2005;60(3):309-316.

33. Molimard M, de Blay F, Didier A, Le Gros V. Effectiveness of omalizumab (Xolair) in the first patients treated in real-life practice in France. Respir Med. 2008;102(1):71-76.

34. Brusselle G, Michils A, Louis R, Dupont L, et al. "Real-life" effectiveness of omalizumab in patients with severe persistent allergic asthma: the PERSIST study. Respir Med. 2009;103(11): $1633-1642$.

35. Korn S, Thielen A, Seyfried S, Taube C, Kornmann O, Buhl R. Omalizumab in patients with severe persistent allergic asthma in a real-life setting in Germany. Respir Med. 2009;103(11): $1725-1731$.

36. Cazzola M, Camiciottoli G, Bonavia M, et al. Italian real-life experience of omalizumab. Respir Med. 2010;104(10):1410-1416. 
37. Vennera MC, Pérez De Llano L, Bardagí S, et al; Spanish Registry. Omalizumab therapy in severe asthma: experience from the Spanish Registry - some new approaches. J Asthma. 2012;49(4):416-422.

38. European Medicines Agency. Xolair. Available from: http:// www.ema.europa.eu/ema/index.jsp?curl=pages/medicines/ human/medicines/000606/human_med_001162.jsp\&mid= WC0b01ac058001d124. Accessed June 6, 2014.

39. Grimaldi-Bensouda L, Zureik M, Aubier M, et al. Does omalizumab make a difference to the real-life treatment of asthma exacerbations? Results from a large cohort of patients with severe uncontrolled asthma. Chest. 2013;143(2):398-405.

40. van den Berge M, Pauw RG, de Monchy JG, van Minnen CA, Postma DS, Kerstjens HA. Beneficial effects of treatment with anti-IgE antibodies (omalizumab) in a patient with severe asthma and negative skin-prick test results. Chest. 2011;139(1):190-193.

41. Menzella F, Piro R, Facciolongo N, Castagnetti C, Simonazzi A, Zucchi L. Long-term benefits of omalizumab in a patient with severe non-allergic asthma. Allergy Asthma Clin Immunol. 2011;7(1):9.

42. de Llano LP, Vennera Mdel C, Alvarez FJ, et al. Effects of omalizumab in non-atopic asthma: results from a Spanish multicenter registry. J Asthma. 2013;50(3):296-301.
43. Garcia G, Magnan A, Chiron R, et al. A proof of concept randomizedcontrolled trial of omalizumab in patients with severe difficult to control nonatopic asthma. Chest. 2013;144(2):411-419.

44. Barnes PJ. Intrinsic asthma: not so different from allergic asthma but driven by superantigens? Clin Exp Allergy. 2009;39(8):1145-1151.

45. Lommatzsch M, Korn S, Buhl R, et al. Against all odds: anti-IgE for intrinsic asthma? Thorax. 2014;69(1):94-96.

46. Pavord ID, Korn S, Howarth P, et al. Mepolizumab for severe eosinophilic asthma (DREAM): a multicentre, double-blind, placebo controlled trial. Lancet. 2012;380(9842):651-659.

47. Gevaert P, Van Bruaene N, Cattaert T, et al. Mepolizumab, a humanized anti-IL-5 mAb, as a treatment option for severe nasal polyposis J Allergy Clin Immunol. 2011;128(5):989-995.

48. Ortega H, Chupp G, Bardin P, et al. The role of mepolizumab in atopic and nonatopic severe asthma with persistent eosinophilia. Eur Respir J. March 23, 2014. [Epub ahead of print.]
International Journal of General Medicine

\section{Publish your work in this journal}

The International Journal of General Medicine is an international, peer-reviewed open-access journal that focuses on general and internal medicine, pathogenesis, epidemiology, diagnosis, monitoring and treatment protocols. The journal is characterized by the rapid reporting of reviews, original research and clinical studies across all disease areas.

\section{Dovepress}

A key focus is the elucidation of disease processes and management protocols resulting in improved outcomes for the patient.The manuscript management system is completely online and includes a very quick and fair peer-review system. Visit http://www.dovepress.com/ testimonials.php to read real quotes from published authors.

Submit your manuscript here: http://www.dovepress.com/international-journal-of-general-medicine-journal 